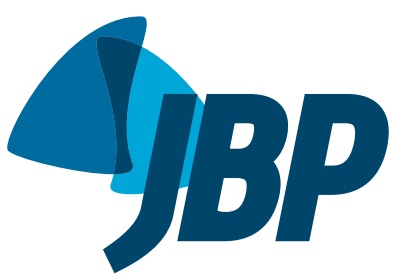

\title{
Reference values for assessing the arms: are we seeing a light at the end of the tunnel?
}

\author{
Luciana Dias Chiavegato', $, 2, \mathrm{a}$
}

Although the systemic changes caused by COPD are well known, respiratory mechanics changes, constant dyspnea, and, therefore, exercise limitation are of note. ${ }^{(1,2)}$ However, for a long time, the major focus of therapeutic care was on the legs. ${ }^{(2,3)}$

Even considering that the legs have an impact on exercise and on such elementary activities as walking, arm activities, especially those involving unsupported arm elevation above the shoulders, result in increased metabolic demand and increased activity of muscles such as thesternocleidomastoid muscle. $(4,5)$ This might culminate in thoracoabdominal asynchrony, as well as in diaphragm and accessory muscle asynchrony, impairing ventilation. ${ }^{(4-7)}$

When it comes to patients with COPD, this asynchrony tends to be even more evident, especially during unsupported arm activities, and these patients may often present with dynamic hyperinflation and exercise-related dyspnea. ${ }^{(6-8)}$

Although, in the case of the legs, activities can be more objectively measured by using accelerometers placed at the hip or legs, information regarding how much and how patients move their arms is still considered limited. ${ }^{(8,9)}$

Since an important systematic review of 41 studies that was conducted by Janaudis-Ferreira et al.,(10) some tests for measuring endurance and functional capacity during unsupported arm exercise, such as the unsupported upper limb exercise test and the six-minute pegboard and ring test (6PBRT), ${ }^{(11)}$ have been recommended.

The 6PBRT was developed by Zhan et al. ${ }^{(11)}$ and is a very simple, inexpensive test that simulates well activities of daily living. During the 6PBRT, the patient has to move
20 rings (10 rings for each arm) from lower wooden pegs to upper wooden pegs, and, once all rings have been moved, he or she has to move them back. The 6PBRT result is expressed as the total number of rings that a subject is able to move back and forth between the sets of pegs in six minutes.

Given that the 6PBRT has been validated(11) and found to be reproducible in healthy subjects, ${ }^{(12)}$ it has become necessary and interesting, both from the standpoint of clinical practice and research, to determine reference values for this test.

Pursuing this track, Lima et al., ${ }^{(13)}$ in a very elegant and well-designed study, conducted 6PBRTs on 104 healthy subjects in order to establish, for the first time, reference values for this test in a healthy population. In the study, the subject distribution by age decade (from age 30 to 80 -plus) is good and there is an appropriate male-tofemale ratio, which causes the proposed equation to have good external validity, allowing it to be generalized to any gender and age group. Although the study took into consideration arm length, upper arm circumference, and forearm circumference, as well as the level of physical activity, only age appears to have influenced the results obtained in the 6PBRT.

Fatigue and dyspnea are often observed during the performance of unsupported arm activities by patients with COPD, limiting them in their activities of daily living. In view of the fact that arm training has been so well incorporated by pulmonary rehabilitation programs, ${ }^{(14)}$ determination of values that can guide us regarding the functioning and endurance of the arms is very important and promising.

\section{REFERENCES}

. EF. Metabolic and ventilatory response pattern to arm elevation in patients with COPD and healthy age-matched subjects. Eur Respir J 1995;8(8):1345-51. https://doi.org/10.1183/09031936.95.08081345

2. McKeough ZJ, Alison JA, Bye PT. Arm exercise capacity and dyspnea ratings in subjects with chronic obstructive pulmonary disease. J Cardiopulm Rehabil. 2003;23(3):218-25. https://doi. org/10.1097/00008483-200305000-00010

3. Hamilton AL, Killian KJ, Summers E, Jones NL. Symptom intensity and subjective limitation to exercise in patients with cardiorespiratory disorders. Chest. 1996;110(5):1255-63. https://doi.org/10.1378/ chest.110.5.1255

4. Dolmage TE, Maestro L, Avendano MA, Goldstein RS. The ventilatory response to arm elevation of patients with chronic obstructive pulmonary disease. Chest. 1993;104(4):1097-100. https://doi.org/10.1378/ chest.104.4.1097
5. Miranda EF, Malaguti C, Corso SD. Peripheral muscle dysfunction in COPD: lower limbs versus upper limbs. J Bras Pneumol. 2011;37(3):3808. https://doi.org/10.1590/S1806-37132011000300016

6. Celli BR, Rassulo J, Make BJ. Dyssynchronous breathing during arm but not leg exercise in patients with chronic airflow obstruction. N Engl J Med. 1986:314(23):1485-90. https://doi.org/10.1056/NEJM198606053142305

7. Lima VP, lamonti VC, Velloso M, Janaudis-Ferreira T. Physiological Responses to Arm Activity in Individuals With Chronic Obstructive Pulmonary Disease Compared With Healthy Controls: A SYSTEMATIC REVIEW. J Cardiopulm Rehabil Prev. 2016;36(6):402-412. https://doi. org/10.1097/HCR.0000000000000190

8. Robles P, Araujo T, Brooks D, Zabjek K, Janaudis-Ferreira T, Marzolini S, et al. Does limb partitioning and positioning affect acute cardiorespiratory responses during strength exercises in patients with COPD? Respirology. 2017;22(7):1336-1342. https://doi.org/10.1111/resp.13056

1. Programa de Mestrado e Doutorado em Fisioterapia, Universidade Cidade de São Paulo, São Paulo (SP) Brasil.

2. Programa de Residência Multiprofissional com Concentração em Distúrbios Respiratórios Clínicos e Cirúrgicos,

Universidade Federal de São Paulo, São Paulo (SP) Brasil.

a. (D) http://orcid.org/0000-0001-6374-3002 
9. Frykholm E, Lima VP, Janaudis-Ferreira T, Nyberg A. Physiological responses to arm versus leg activity in patients with chronic obstructive pulmonary disease: a systematic review protocol. BMJ Open. 2018;8(2):e019942. https://doi.org/10.1136/bmjopen-2017-019942

10. Janaudis-Ferreira T, Beauchamp MK, Goldstein RS, Brooks D. How should we measure arm exercise capacity in patients with COPD? A systematic review. Chest. 2012;141(1):111-120. https://doi. org/10.1378/chest.11-0475

11. Zhan S, Cerny FJ, Gibbons WJ, Mador MJ, Wu WY. Development of an unsupported arm exercise test in patients with chronic obstructive pulmonary disease. J Cardiopulm Rehabil. 2006;26(3):180-7; discussion 188-90. https://doi.org/10.1097/00008483-200605000-00013
12. Lima VP, Velloso M, Almeida FD, Carmona B, Ribeiro-Samora GA Janaudis-Ferreira T. Test-retest reliability of the unsupported upperlimb exercise test (UULEX) and 6-min peg board ring test (6PBRT) in healthy adult individuals. Physiother Theory Pract. 2018 Jan 19:1-7. [Epub ahead of print] https://doi.org/10.1080/09593985.2018.14257 86

13. Lima VP, Almeida FD, Janaudis-Ferreira T, Carmona B, Ribeiro-Samora GA, Velloso M. Reference values for the six-minute pegboard and ring test in healthy adults in Brazil. J Bras Pneumol. 2018;44(3):190-4.

14. McKeough ZJ, Velloso M, Lima VP, Alison JA. Upper limb exercise training for COPD. Cochrane Database Syst Rev. 2016;11:CD011434. https://doi.org/10.1002/14651858.CD011434.pub2 